\title{
PENGARUH KUALITAS PRODUK DAN HARGA TERHADAP KEPUASAN KONSUMEN PRODUK WIFI.ID PT TELEKOMUNIKASI INDONESIA TBK. WITEL SUMUT
}

\author{
Oleh: \\ Dessy Anggraeini \\ S1 Manajemen \\ Darwin Lie, Marisi Butarbutar, Fitria Halim
}

Abstraksi

Hasil penelitian: 1. Kualitas produk yang diberikan sudah baik, dan konsumen setuju dengan harga yang ditawarkan, serta konsumen sudah puas terhadap kepuasan konsumen. 2. Hasil analisis regresi adalah $\ddot{Y}=9,934+0,428 X_{1}+0,733 X_{2}$, artinya kualitas produk dan harga berpengaruh positif terhadap kepuasan konsumen. 3. Hasil analisis korelasi diperoleh nilai $r=0,652$ artinya terdapat hubungan yang kuat dan positif antara kualitas produk dan harga dengan kepuasan konsumen. Kepuasan konsumen dipengaruhi oleh kualitas produk dan harga sebesar 42,5\%. 4. Hipotesis penelitian $\mathrm{H}_{0}$ ditolak dan $\mathrm{H}_{\mathrm{a}}$ diterima, artinya kualitas produk dan harga berpengaruh positif dan signifikan terhadap kepuasan konsumen produk WiFi.ID PT Telekomunikasi Indonesia Tbk. Witel Sumut baik secara simultan maupun parsial.

Adapun saran dari penelitian ini adalah perlu dilakukan peningkatan kestabilan akses produk, menambah kecepatan akses produk, dan peningkatkan spesifikasi produk WiFi.ID. Untuk mempertahankan harga yang terjangkau, sebaiknya memberikan kompensasi berupa diskon/potongan harga kepada konsumen yang membeli dengan jumlah tertentu, dan menambah besaran diskon/potongan harga. Sedangkan untuk meningkatkan kepuasan konsumen, perlu meningkatkan kepedulian terhadap keinginan konsumen, serta memberi respon yang baik dan cepat terhadap keluhan yang dirasakan konsumen mengenai produk WiFi.ID.

Kata kunci: Kualitas Produk, Harga, dan Kepuasan Konsumen.

\section{Abstraction}

The result of this research: 1 . The product quality that provided are good, and consumers are agree with the price offered, and the consumers are satisfied to consumer satisfaction. 2 . The results of regression analysis is $\overline{\mathrm{Y}}=9,934+0,428 \mathrm{X}_{1}+0,733 \mathrm{X}_{2}$, it means the product quality and price has positive influence to consumer satisfaction. 3 . The results of correlation analysis obtained by $r=0.652$ means that there is a strong and positive relationship between product quality and price with consumer satisfaction. Consumer satisfaction is influenced by the product quality and price by $42.5 \%$. 4. The hypothesis of research $H_{0}$ is rejected and $H_{a}$ is accepted, it means the product quality and price, has a positive and significant influence to consumer satisfaction of WiFi.ID's product at PT Telekomunikasi Indonesia Tbk Witel Sumut either simultanous or partially.

The suggestion of this research it's necessary to increase the stability of product access, increase the access speed of product, and increasing the specifications of WiFi.ID's product. To maintain reasonable prices, should provide compensation in the form of discounts/rebates to consumer who buy a certain amount, and increase the amount of discount/rebate. Meanwhile, to improve customer satisfaction, need to raise awareness to consumer about the wishes of consumer, and give favorably and quickly responses for the consumer who complain about WiFi.ID's product.

Keywords: Product Quality, Price, and Consumer Satisfaction.

\section{A. PENDAhULUAN}

1. Latar Belakang Masalah

PT Telekomunikasi Indonesia Tbk. merupakan salah satu Badan Usaha Milik Negara (BUMN) yang menyediakan berbagai jenis produk layanan telekomunikasi. Salah satunya adalah WiFi.ID atau Indonesia WiFi yang merupakan jaringan akses broadband yang menyediakan layanan publik, yaitu internet berbasis teknologi WiFi Hotspot yang dapat diperoleh dengan membeli voucher atau melakukan registrasi melalui SMS (Short Message Service).
Fenomena pada mahasiswa STIE Sultan Agung Pematangsiantar, yaitu adanya peningkatan jumlah mahasiswa yang menggunakan produk WiFi.ID di lingkungan kampus. Untuk mempertahankan dan meningkatkan jumlah konsumen produk WiFi.ID di STIE Sultan Agung Pematangsiantar, maka PT Telekomunikasi Indonesia Tbk. perlu menciptakan kepuasan konsumen. Terdapat banyak faktor yang mempengaruhi kepuasan konsumen, beberapa diantaranya adalah kualitas produk dan harga. 
Dimensi kualitas produk terdiri dari kinerja, fitur, reliabilitas, daya tahan, estetika, dan kesesuaian dengan spesifikasi. Kinerja produk WiFi.ID tergambar melalui kualitas jaringan, kestabilan akses, dan kecepatan akses, yaitu up to 100 Mbps (Mega bit per second). Fitur atau kestimewaan yang dimiliki produk WiFi.ID adalah memiliki kuota yang tidak terbatas (unlimited), serta dapat digunakan untuk beberapa perangkat (multi device).

Reliabilitas produk WiFi.ID dapat dirasakan melalui konektivitas produk WiFi.ID, kestabilan dari gangguan jaringan, serta adanya petunjuk penggunaan (user guide) pada voucher. Produk WiFi.ID memiliki daya tahan (masa aktif) selama 12 jam setelah registrasi. Estetika produk WiFi.ID tergambar melalui desain voucher dan homepage WiFi.ID Kesesuaian produk yang diterima konsumen dengan spesifikasi dapat meningkatkan kepuasan konsumen.

Selain kualitas produk, harga merupakan komponen penting atas suatu produk yang menjadi pertimbangan konsumen untuk membeli. Harga adalah sejumlah nilai atas suatu produk yang dibebankan kepada konsumen atas manfaat-manfaat karena memiliki atau menggunakan produk tersebut. Dimensi harga terdiri dari keterjangkauan harga, diskon/potongan harga, dan cara pembayaran.

Harga yang ditawarkan PT Telekomunikasi Indonesia Tbk. adalah Rp $5.000,00$ (lima ribu rupiah) dengan masa aktif 12 jam, baik pembelian voucher maupun potong pulsa dengan mengirim SMS dengan format NET (spasi) 5000 ke 98108. Pemberian diskon/potongan harga masih jarang dilakukan. Cara pembayaran dilakukan secara langsung maupun melalui pemotongan pulsa seluler.

Kualitas produk yang mumpuni serta harga yang terjangkau akan meningkatkan kepuasan konsumen.

\section{Rumusan Masalah}

a. Bagaimana gambaran kualitas produk, harga dan kepuasan konsumen produk WiFi.ID PT Telekomunikasi Indonesia Tbk. Witel Sumut.

b. Bagaimana pengaruh kualitas produk dan harga terhadap kepuasan konsumen produk WiFi.ID PT Telekomunikasi Indonesia Tbk. Witel Sumut baik secara simultan maupun parsial.

\section{Tujuan Penelitian}

a. Untuk mengetahui gambaran kualitas produk, harga dan kepuasan konsumen produk WiFi.ID PT Telekomunikasi Indonesia Tbk. Witel Sumut.

b. Untuk mengetahui pengaruh kualitas produk dan harga terhadap kepuasan konsumen produk WiFi.ID PT Telekomunikasi Indonesia
Tbk. Witel Sumut baik secara simultan maupun parsial.

\section{Metode Penelitian}

Objek penelitian adalah STIE Sultan Agung Pematangsiantar yang terletak di Jalan Surabaya No. 19 Pematangsiantar - 21118 Sumatera Utara. Populasi adalah mahasiswa STIE Sultan Agung Pematangsiantar semester VI tahun akademik 2015/2016 yang berjumlah 240 orang. Setelah dihitung dengan rumus Slovin, maka sampel adalah 142 orang.

Desain penelitian adalah Penelitian Kepustakaan (Library Research) dan Penelitian Lapangan (Field Research). Teknik pengumpulan data berupa Kuesioner, Wawancara dan Dokumentasi. Jenis data yang adalah jenis data kualitatif dan data kuantitatif. Hasil data yang diperoleh dari lapangan akan dianalisis secara deskriptif baik bersifat kualitatif dan kuantitatif.

\section{B. LANDASAN TEORI}

\section{Manajemen Pemasaran}

Menurut Kotler dan Gary (2001:18), manajemen pemasaran merupakan analisis, perencanaan, implementasi, dan pengendalian dari program-program yang dirancang untuk menciptakan, membangun, dan memelihara pertukaran yang menguntungkan dengan pemberi sasaran untuk mencapai tujuan perusahaan. Sedangkan menurut Kotler dan Kevin (2009:5), manajemen pemasaran (marketing management) merupakan seni dan ilmu memilih pasar sasaran dan meraih, mempertahankan, serta menumbuhkan pelanggan dengan menciptakan, menghantarkan, dan mengkomunikasikan nilai pelanggan yang unggul. Berdasarkan uraian teori di atas, maka dapat disimpulkan bahwa manajemen pemasaran adalah pemilihan pasar sasaran dengan melakukan analisis, perencanaan, implementasi, dan pengendalian dari program-program yang dirancang, yang dilakukan untuk menciptakan, menghantarkan, dan mempertahankan pertukaran yang menguntungkan dengan mencapai nilai pelanggan yang unggul untuk mewujudkan tujuan perusahaan.

\section{Kualitas Produk}

Menurut Kotler (2005:49), kualitas adalah seluruh ciri serta sifat suatu produk atau pelayanan yang berpengaruh pada kemampuan untuk memuaskan kebutuhan yang dinyatakan atau yang tersirat. Definisi kualitas menurut Prawirosentono (2007:5) adalah keadaan fisik, fungsi, dan sifat suatu produk bersangkutan yang dapat memenuhi selera dan kebutuhan konsumen dengan memuaskan sesuai nilai uang yang telah dikeluarkan. Berdasarkan uraian teori di atas, maka dapat disimpulkan bahwa kualitas adalah ciri atau karakteristik 
suatu produk yang memperlihatkan fisik, fungsi, dan sifat suatu produk yang dapat menentukan terpenuhinya kebutuhan konsumen dengan tercapainya kepuasan konsumen.

Menurut Alma (2000:98), produk adalah seperangkat atribut baik berwujud maupun tidak berwujud, termasuk di dalamnya masalah warna, harga, nama baik pabrik, nama baik toko yang menjual (pengecer), dan pelayanan pabrik serta pelayanan pengecer, yang diterima oleh pembeli guna memuaskan keinginannya. Berdasarkan uraian pendapat beberapa ahli di atas, maka dapat disimpulkan bahwa produk adalah seperangkat atribut yang dapat ditawarkan kepada pasar untuk digunakan oleh konsumen, baik berwujud maupun tidak berwujud.

Menurut Tjiptono (2001:347), terdapat enam dimensi yang digunakan untuk menganalisis karakteristik kualitas produk, yaitu: kinerja, ciri-ciri atau keistimewaan tambahan, kehandalan, kesesuaian dengan spesifikasi, daya tahan, dan estetika

\section{Harga}

Menurut Kotler dan Gary (2008:345) harga (price) adalah sejumlah uang yang ditagihkan atas suatu produk atau jasa, atau jumlah dari nilai yang ditukarkan para pelanggan untuk memperoleh manfaat dari memiliki atau menggunakan suatu produk atau jasa. Sedangkan menurut Kotler dan Kevin (2009:67), harga adalah elemen termuda dalam program pemasaran untuk disesuaikan, fitur produk, saluran, dan bahkan komunikasi membutuhkan banyak waktu. Berdasarkan uraian pendapat ahli di atas, maka dapat disimpulkan bahwa harga merupakan salah satu elemen pemasaran yang berupa sejumlah uang yang ditagihkan atas suatu produk, yang disesuaikan dengan fitur produk, saluran, dan komunikasi untuk memperoleh manfaat dari memiliki atau menggunakan suatu produk.

Menurut Kotler dan Gary (2008:452), harga dapat diukur dengan beberapa indikator, yaitu: keterjangkauan harga, diskon/potongan harga, dan cara pembayaran.

\section{Kepuasan Konsumen}

\section{Menurut Sumarwan}

(2004:322), kepuasan konsumen merupakan dampak dari perbandingan antara harapan pelanggan sebelum pembelian dengan sesungguhnya diperoleh konsumen dari produk yang dibeli tersebut. Sedangkan menurut Kotler (2005:70), kepuasan pelanggan adalah perasaan atau kecewa seseorang yang muncul setelah membandingkan antara kinerja (hasil) produk yang dipikirkan terhadap kinerja yang diharapkan. Berdasarkan uraian pendapat beberapa ahli di atas, maka dapat disimpulkan bahwa kepuasan konsumen adalah dampak dari perbandingan antara harapan dengan sesungguhnya dari konsumen yang berupa perasaan yang muncul setelah membeli dan menggunakan produk.

Menurut Lupiyoadi dan Hamdani (2001:158), dalam menentukan kepuasan konsumen terdapat lima faktor yang perlu diperhatikan oleh perusahaan, yaitu: kualitas produk, kualitas pelayanan atau jasa, emosi, harga, dan biaya.

\section{PEMBAHASAN}

\section{Analisa}

\section{a. Deskriptif Kualitatif}

Analisis deskriptif dimaksudkan untuk mendapatkan gambaran atau deskripsi mengenai tanggapan dari konsumen mengenai Pengaruh Kualitas Produk dan Harga terhadap Kepuasan Konsumen Produk WiFi.ID PT Telekomunikasi Indonesia Tbk. Witel Sumut. Setelah pengujian data, maka langkah selanjutnya peneliti melakukan pengkajian analisis kualitatif sebagai gambaran fenomena dari variabel penelitian pada saat sekarang ini. Adapun penetapan kriteria nilai rata-rata jawaban dari responden tersebut dimasukkan ke dalam kelas-kelas interval dimana penentuan intervalnya memakai rumus sebagai berikut:

Interval Kelas $=$ Nilai Tertinggi - Nilai Terendah

$$
\begin{aligned}
& =\frac{5-1}{5} \\
& =\frac{4}{5} \\
& =0,8
\end{aligned}
$$

Dari rumus diatas dapat diperoleh interval kelas 0,8 sehingga berlaku ketentuan kategori dengan hasil berikut:

Tabel 1

Nilai Interval dan Kategori Jawaban Responden.

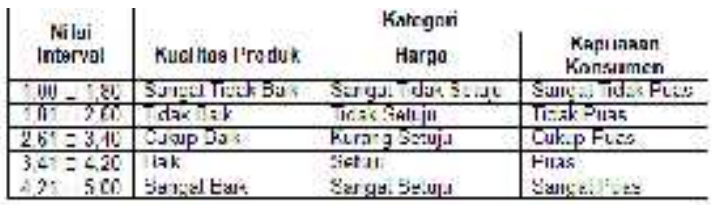

Sumber : hasil pengolahan data

\section{1) Gambaran Kualitas Produk pada Produk WiFi.ID PT Telekomunikasi Indonesia Tbk. Witel Sumut}

Dari hasil analisa, dapat dilihat bahwa untuk dimensi kinerja (performances) pada indikator kualitas jaringan produk WiFi.ID memiliki nilai rata-rata 3,92 dengan kriteria jawaban baik. Hal ini disebabkan produk WiFi.ID memiliki kualitas jaringan yang baik, dan jaringan WiFi.ID didukung oleh banyaknya access point yang terletak di berbagai tempat umum, khusunya di STIE Sultan Agung Pematangsiantar. Pada indikator kestabilan akses produk WiFi.ID memiliki nilai rata-rata 
3,74 dengan kriteria jawaban baik. Hal ini disebabkan produk WiFi.ID memiliki kestabilan akses yang dapat mendukung kelancaran para mahasiswa untuk menyelesaikan tugas-tugas atau mencari informasi.

Pada indikator kecepatan akses produk WiFi.ID memiliki nilai rata-rata 3,76 dengan kriteria jawaban baik. Hal ini disebabkan produk WiFi.ID memiliki kecepatan up to $10 \mathrm{Mbps}$ (Mega bit per second) untuk setiap satu access point yang akan membuat kegiatan menjelajah dunia maya semakin efisien. Selanjutnya dimensi fitur (features) pada indikator kemudahan proses registrasi memiliki nilai ratarata 3,82 dengan kriteria jawaban baik. Hal ini disebabkan proses registrasi yang mudah dilakukan dan tidak berbelit-belit. Registrasi dapat dilakukan dengan dua cara, yaitu dengan membeli voucher di Plasa Telkom atau outletoutlet terdekat yang menyediakan pembelian voucher WiFi.ID, serta melalui SMS dengan format NET (spasi) 5000 ke 98108.

Pada indikator kapasitas kuota yang tidak terbatas (unlimited) pada produk WiFi.ID memiliki nilai rata-rata 3,93 dengan kriteria jawaban baik. Hal ini disebabkan kuota yang tidak terbatas akan memberi kebebasan kepada konsumen untuk mengunduh apa saja yang mereka inginkan tanpa khawatir akan kehabisan kuota. Pada indikator voucher WiFi.ID yang dapat digunakan untuk lebih dari satu perangkat (multi device) memiliki nilai ratarata 3,85 dengan kriteria jawaban baik. Hal ini disebabkan user name dan password yang diperoleh dari voucher dapat digunakan $\mathrm{d}$ perangkat lain.

Untuk dimensi reliabilitas (reliability) pada indikator konektivitas produk WiFi.ID memiliki nilai rata-rata 3,90 dengan kriteria jawaban baik, disebabkan konektivitas produk WiFi.ID stabil dan tidak terputus-putus selama masih berada dalam jangkauan accsess point. Pada indikator kestabilan produk WiFi.ID dari gangguan jaringan memiliki nilai rata-rata 3,54 dengan kriteria jawaban baik. Hal ini disebabkan kestabilan dari gangguan jaringan merupakan hal penting yang perlu diperhatikan ketika menggunakan jaringan internet, sebab hal tersebut dapat mempengaruhi kelancaran dalam mengakses jaringan internet. Pada indikator petunjuk penggunaa (user guide) yang tertera pada voucher produk WiFi.ID memiliki nilai rata-rata 3,66 dengan kriteria jawaban baik, hal ini disebabkan terdapat petunjuk penggunaan (user guide) yang tertera dibagian belakang voucher WiFi.ID, sehingga mempermudah konsumen mengetahui cara penggunaannya yang tepat.

Dimensi daya tahan (durability) pada indikator produk WiFi.ID yang dapat digunakan selama rentang waktu 12 jam setelah registrasi memiliki nilai rata-rata 3,90 dengan kriteria jawaban baik, disebabkan produk WiFi.ID yang masih dapat digunakan selama 12 jam setelah registrasi membuat jangka waktu penggunaan yang relatif lebih lama. Pada indikator masa berlaku voucher produk WiFi.ID yang cukup panjang memiliki nilai rata-rata 3,86 dengan kriteria jawaban baik. Hal ini disebabkan setiap voucher produk WiFi.ID memiliki masa berlaku atau masa aktif hingga 18 bulan seperti yang tertera pada voucher, sehingga jika voucher sudah dibeli namun belum digunakan konsumen tidak perlu khawatir tentang masa berlaku atau masa aktif voucher, karena memiliki rentang waktu yang cukup lama.

Pada indikator proses registrasi yang dapat dilakukan selama voucher berada dalam masa aktif memiliki nilai rata-rata 3,67 dengan kriteria jawaban baik, disebabkan proses registrasi dapat dilakukan kapan saja pada saat voucher masih berada dalam masa aktif yang telah ditentukan. Selanjutnya dimensi estetika (aesthetics),pada indikator desain yang terdapat pada voucher produk WiFi.ID memiliki nilai ratarata 3,73 dengan kriteria jawaban baik. Voucher WiFi.ID memiliki desain yang sederhana dan tidak terlalu ramai dengan ornamen hiasan.

Pada indikator desain yang terdapat pada homepage WiFi.ID memiliki nilai rata-rata 3,83 dengan kriteria jawaban baik. Hal ini disebabkan desain pada homepage WiFi.ID tidak terlalu menggunakan banyak ornamen, sehingga tidak membingungkan konsumen dalam penggunannya. Pada indikator pilihan warna yang digunakan pada voucher produk WiFi.ID memiliki nilai rata-rata 3,80 dengan kriteria jawaban baik. Hal ini disebabkan voucher produk WiFi.ID memiliki pilihan warna yang tidak terlalu banyak, dengan warna utama merah dan warna tulisan putih. Pada indikator pilihan warna yang digunakan pada homepage WiFi.ID memiliki nilai rata-rata 3,78 dengan kariteria jawaban baik. Hal ini disebabkan pilihan warna yang digunakan di homepage WiFi.ID tidak jauh berbeda dengan pilihan warna pada voucher yang masih konsisten mengusung warna merah dan putih, dengan beberapa tambahan warna biru muda serta hijau muda yang digunakan pada gambar yang terdapat pada homepage WiFi.ID.

Dimensi kesesuaian dengan spesifikasi (conformance to spesification) pada indikator kesesuaian masa aktif yang tertera pada voucher produk WiFi.ID dengan masa aktif yang sebenarnya memiliki nilai rata-rata 3,70 dengan kriteria jawaban baik. Hal ini disebabkan masa aktif yang tertera pada voucher produk WiFi.ID memiliki kesesuaian dengan masa aktif yang sebenarnya, dan merupakan informasi yang penting bagi konsumen, agar konsumen dapat memberikan perlakuan yang benar terhadap produk yang akan digunakan. Pada indikator kesesuaian spesifikasi kecepatan akses dengan kecepatan akses yang sebenarnya memiliki nilai rata-rata 3,77 dengan kriteria jawaban baik. 
Hal ini disebabkan spesifikasi kecepatan akses produk WiFi.ID adalah up to 100 Mbps (Mega bit per second). Pada indikator kesesuaian spesifikasi produk WiFi.ID dengan harapan konsumen memiliki nilai rata-rata 3,69 dengan kriteria jawaban baik. Hal ini disebabkan spesifikasi yang dimiliki produk WiFi.ID menyesuaikan dengan kebutuhan konsumen, sehingga dapat memenuhi harapan konsumen. Spesifikasi produk menjadi salah satu faktor konsumen menggunakan suatu produk.

Secara keseluruhan dapat dilihat bahwa nilai rata-rata untuk variabel kualitas produk berdasarkan jawaban responden adalah 3,78 dengan kriteria jawaban baik. Nilai rata-rata yang tertinggi sebesar 3,93 dengan kriteria jawaban baik diperoleh dimensi fitur (features) pada indikator kapasitas kuota yang tidak terbatas (unlimited) pada produk WiFi.ID. Sedangkan nilai rata-rata terendah sebesar 3,54 dengan kriteria jawaban baik diperoleh dimensi reliabilitas (reliability) pada indikator kestabilan produk WiFi.ID dari gangguan jaringan.

\section{2) Gambaran Harga pada Produk WiFi.ID PT Telekomunikasi Indonesia Tbk. Witel Sumut}

Dari hasil analisa, dapat dilihat bahwa untuk dimensi keterjangkauan harga pada indikator harga produk WiFi.ID dapat dijangkau oleh konsumen memiliki nilai rata-rata 4,13 dengan kriteria jawaban setuju. $\mathrm{Hal}$ in disebabkan harga produk WiFi.ID senilai $\mathrm{Rp}$ 5000,00 (lima ribu rupiah) dan dapat digunakan selama 12 jam dianggap dapat dijangkau oleh konsumen produk WiFi.ID khususnya kalangan mahasiswa, karena relatif murah. Pada indikator harga produk WiFi.ID sesuai dengan spesifikasi yang ditawarkan memiliki nilai ratarata 4,04 dengan kriteria jawaban setuju. Hal ini disebabkan harga yang terjangkau dan relatif murah, menyebabkan tingkat spesifikasi yang ditawarkan produk WiFi.ID sudah sesuai dan dapat memenuhi kebutuhan konsumen. Pada indikator harga produk WiFi.ID di outlet-outlet tidak berbeda dengan harga produk WiFi.ID di Plasa Telkom memiliki nilai rata-rata 3,86 dengan kriteria jawaban setuju. Hal ini disebabkan kesamaan harga produk WiFi.ID di outlet dengan Plasa Telkom merupakan pertimbangan bagi konsumen untuk menentukan tempat pembelian produk WiFi.ID.

Selanjutnya dimensi diskon/potongan harga, pada indikator PT Telekomunikasi Indonesia Tbk. Witel Sumut memberikan diskon/potongan harga pada pembelian produk WiFi.ID memiliki niilai rata-rata 3,72 dengan kriteria jawaban setuju. Hal ini disebabkan harga yang ditawarkan sudah relatif murah tanpa pemberian diskon/potongan harga, sehingga untuk pembelian produk WiFi.ID, PT Telekomunikasi Indonesia Tbk. tidak sering memberikan diskon/potongan harga. Pada indikator diskon/potongan harga yang diberikan relatif banyak memiliki nilai rata-rata 3,66 dengan kriteria jawaban setuju. Hal ini disebabkan pemberian diskon/potongan harga pada pembelian produk WiFi.ID akan meningkatkan daya beli konsumen. Pada indikator pemberian diskon/potongan harga yang diberikan bersifat rutin memiliki nilai ratarata 3,65 dengan kriteria jawaban setuju. Hal ini disebabkan diskon/potongan harga yang diberikan untuk pembelian produk WiFi.ID belum bersifat rutin.

Sedangkan untuk dimensi cara pembayaran, pada indikator kemudahan cara pembayaran memiliki nilai rata-rata 4,00 dengan kriteria jawaban setuju. Hal ini disebabkan cara pembayaran untuk pembelian produk WiFi.ID tidak melalui proses panjang yang berbelit. Pada indikator pembayaran dilakukan langsung secara tunai memiliki nilai rata-rata 3,88 dengan kriteria jawaban setuju. Hal ini disebabkan pembayaran untuk pembelian produk WiFi.ID baik berupa voucher maupun melalui SMS (Short Message Service) dilakukan langsung secara tunai. Pada indikator pembayaran dapat dilakukan dimana saja memiliki nilai rata-rata 3,93 dengan kriteria jawaban setuju. Hal ini disebabkan pembayaran yang dapat dilakukan dimana saja akan memudahkan konsumen untuk melakukan transaksi pembayaran.

Secara keseluruhan dapat dilihat bahwa nilai rata-rata variabel harga adalah sebesar 3,87 dengan kriteria jawaban setuju. Nilai ratarata tertinggi sebesar 4,13 dengan kriteria jawaban setuju diperoleh dimensi keterjangkauan harga pada indikator haga produk WiFi.ID dapat dijangkau oleh konsumen. Sedangkan nilai rata-rata yang terendah sebesar 3,65 dengan kriteria jawaban setuju diperoleh dimensi diskon/potongan harga pada indikator pemberian diskon/potongan harga yang diberikan bersifat rutin.

\section{3) Gambaran Kepuasan Konsumen pada Produk WiFi.ID PT Telekomunikasi Indonesia Tbk. Witel Sumut}

Dari hasil analisa, dapat dilihat bahwa untuk dimensi kualitas produk pada indikator kinerja produk WiFi.ID memiliki nilai rata-rata 3,86 dengan kriteria jawaban puas, disebabkan kinerja produk WiFi.ID mampu memenuhi kebutuhan konsumen. Pada indikator fitur yang dimiliki produk WiFi.ID memiliki nilai rata-rata 3,78 dengan kriteria jawaban puas. Hal ini disebabkan produk WiFi.ID memiliki fitur yang mampu mendukung memenuhi harapan konsumen serta menambah keistimewaan produk WiFi.ID. Pada indikator reliabilitas/kehandalan pada produk WiFi.ID memiliki nilai rata-rata 3,62 dengan kriteria jawaban puas. Hal ini disebabkan produk 
WiFi.ID memiliki konektivitas yang tidak terputus-putus, kestabilan produk dari gangguan jaringan, serta adanya petunjuk penggunaan pada voucher produk WiFi.ID.

Pada indikator daya tahan yang dimiliki produk WiFi.ID memiliki nilai rata-rata 3,67 dengan kriteria jawaban puas. Hal ini disebabkan produk WiFi.ID memiliki daya tahan atau masa aktif voucher hingga 18 bulan, serta masa aktif setelah registrasi selama 24 jam. Pada indikator estetika yang dimiliki produk WiFi.ID memiliki nilai rata-rata 3,61 dengan kriteria jawaban puas. Hal ini disebabkan estetika produk WiFi.ID yang tergambar pada desain serta pemilihan warna yang tepat pada voucher dan homepage. Pada indikator kesesuaian dengan spesifikasi yang terdapat pada produk WiFi.ID memiliki nilai rata-rata 3,64 dengan kriteria jawaban puas. Hal ini disebabkan produk WiFi.ID memiliki kesesuaian dengan spesifikasinya.

Selanjutnya untuk dimensi kualitas pelayanan, pada indikator kemudahan dalam menyampaikan keluhan tentang produk WiFi.ID memiliki nilai rata-rata 3,64 dengan kriteria jawaban puas. hal ini disebabkan konsumen yang ingin menyampaikan keluhan dapat menghubungi call center dengan nomor 147 atau langsung mengunjungi Plasa Telkom terdekat. Pada indikator respon yang diberikan oleh karyawan PT Telekomunikasi Indonesia Tbk. Witel Sumut dalam mengatasi keluhan konsumen mengenai produk WiFi.ID memiliki nilai rata-rata 3,59 dengan kriteria jawaban puas. Hal ini disebabkan setiap keluhan yang disampaikan oleh konsumen akan ditanggapi oleh karyawan PT Telekomunikasi Indonesia Tbk. Witel Sumut sebagai bentuk kepedulian terhadap konsumen.

Pada indikator kemampuan karyawan PT Telekomunikasi Indonesia Tbk. Witel Sumut dalam memberikan solusi atas keluhan konsumen mengenai produk WiFi.ID memiliki nilai rata-rata 3,62 dengan kriteria jawaban puas. Hal ini disebabkan keluhan konsumen akan ditangani oleh karyawan PT Telekomunikasi Indonesia Tbk. Witel Sumut yang telah profesional dan berpengalaman di bidangnya masing-masing, sehingga keluhan yang dirasakan konsumen dapat ditangani secara tepat.

Untuk dimensi emosi, pada indikator perasaan bangga yang dirasakan konsumen ketika menggunakan produk WiFi.ID miliki PT Telekomunikasi Indonesia Tbk. memiliki nilai rata-rata 3,75 dengan kriteria jawaban puas. Hal ini disebabkan produk WiFi.ID miliki PT Telekomunikasi Indonesia Tbk. memiliki citra yang baik di masyarakat, sehingga konsumen akan memiliki perasaan bangga tersendiri ketika menggunakannya. Pada indikator perasaan konsumen setelah menggunakan produk WiFi.ID memiliki nilai rata-rata 3,73 dengan kriteria jawaban puas. Hal ini disebabkan kepuasan konsumen yang dirasakan setelah menggunakan produk WiFi.ID akan menghasilkan getok tular positif, sebalikanya ketidakpuasan konsumen akan menghasilkan getok tular negatif, hal tersebut akan berpengaruh terhadap perusahaan.

Pada indikator tercapainya harapan konsumen mengenai kemampuan produk WiFi.ID memenuhi kebutuhan konsumen akan jaringan internet memiliki nilai rata-rata 3,74 dengan kriteria jawaban puas. Hal ini disebabkan ketika harapan konsumen tercapai pada saat menggunakan produk WiFi.ID, maka kepuasan konsumen akan terwujud.

Selanjutnya dimensi harga, pada indikator keterjangkauan harga produk WiFi.ID memiliki nilai rata-rata 3,94 . Hal ini disebabkan produk WiFi.ID memiliki harga yang terjangkau, terutama bagi kalangan mahasiswa, yang membutuhkan produk berkualitas namun terjangkau. Pada indikator intensitas pemberian diskon/potongan harga memiliki nilai rata-rata 3,54 dengan kriteria jawaban puas. Hal ini disebabkan pemberian diskon/potongan harga untuk pembelian produk WiFi.ID tidak terlalu intens. Pada indikator kemudahan cara pembayaran untuk produk WiFi.ID memiliki nilai rata-rata 3,80 dengan kriteria jawaban puas. Hal ini disebabkan pembayaran untuk pembelian produk WiFi.ID yang tidak berbelitbelit dan tidak perlu mengantri, bahkan konsumen dapat membayar pembelian melalui pemotongan pulsa.

Sedangkan untuk dimensi promosi, pada pemberian promo produk WiFi.ID memiliki nilai rata-rata 3,65 dengan kriteria jawaban puas. Hal ini disebabkan masyarakat sudah mengenal produk ini beserta kualitasnya, sehingga PT Telekomunikasi Indonesia Tbk. jarang melakukan promo untuk produk WiFi.ID. Pada indikator intensitas pemberian promo produk WiFi.ID memiliki nilai rata-rata 3,53 dengan kriteria jawaban puas. Hal ini disebabkan pemberian promo untuk produk WiFi.ID tidak terlalu intens dilakukan oleh PT Telekomunikasi Indonesia Tbk, hanya pada hari-hari tertentu saja.

Pada indikator kuantitas promo yang diberikan untuk produk WiFi.ID memiliki nilai rata-rata 3,53 dengan kriteria jawaban puas. Hal ini disebabkan PT Telekomunikasi Indonesia Tbk. melakukan promo berhadiah barang-barang elektronik dengan jumlah yang terbatas, sehingga hanya diperuntukkan bagi konsumen yang beruntung, dan memiliki poin yang cukup.

Secara keseluruhan dapat dilihat bahwa nilai rata-rata variabel kepuasan konsumen adalah sebesar 3,68 . Nilai rata-rata tertinggi adalah sebesar 3,94 dengan kriteria jawaban puas diperoleh dimensi harga dengan indikator keterjangkauan harga produk WiFi.ID. 
Sedangkan nilai rata-rata terendah adalah sebesar 3,53 dengan kriteria jawaban puas diperoleh dimensi promosi, dengan indikator intensitas pemberian promo produk WiFi.ID dan indikator kuantitas promo yang diberikan untuk produk WiFi.ID.

\section{b. Deskriptif Kuantitatif}

\section{1) Regresi Linear Berganda}

Penelitian ini memiliki tujuan untuk menganalisis pengaruh kualitas produk dan harga terhadap kepuasan konsumen. Analisis data dalam penelitian ini menggunakan analisis regresi linier berganda. Analisis regresi linier berganda digunakan untuk mengetahui pengaruh variabel bebas $(X)$ dan variabel terikat $(Y)$, dimana $X$ adalah kualitas produk, harga, dan $Y$ adalah kepuasan konsumen. Maka dilakukan perhitungan menggunakan program aplikasi SPSS versi 20 dengan hasil hitung regresi sebagai berikut:

\section{Tabel 2}

Hasil Regresi Linier Berganda

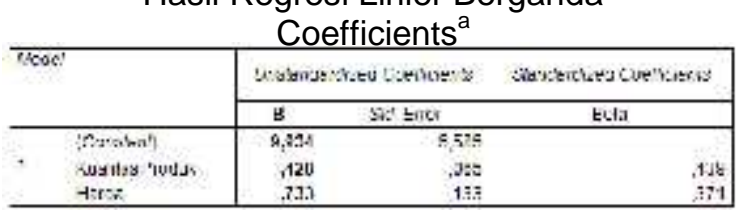

a. Dependent Variabel: Kepuasan Konsumen Sumber: hasil pengolahan data dengan SPSS versi 20

Berdasarkan hasil pengolahan data pada tabel 2 di atas diperoleh model persamaan $\overline{\mathrm{Y}}=$ $9,934+0,428 X_{1}+0,733 X_{2}$ artinya terdapat pengaruh yang positif antara variabel kualitas produk $\left(\mathrm{X}_{1}\right)$ dan harga $\left(\mathrm{X}_{2}\right)$ terhadap variabel terikat kepuasan konsumen $(\mathrm{Y})$ pada produk WiFi.ID PT Telekomunikasi Indonesia Tbk. Witel Sumut.

\section{2) Koefisien Korelasi dan Koefisien Determinasi}

Hasil koefisien korelasi dan koefisien determinasi dapat dilihat pada tabel berikut:

Tabel 3

Hasil Koefisien Korelasi dan Determinas Model Summary ${ }^{\mathrm{b}}$

\begin{tabular}{|c|c|c|c|c|}
\hline thuoter & $R$ & R.Squ: & 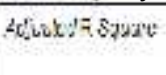 & $\begin{array}{l}\text { Sid Engerily } \\
\text { Eshiare }\end{array}$ \\
\hline 1 & $.55 \%$ & 475 & $\therefore T$ & 苚 \\
\hline
\end{tabular}

a. Predictors: (Constant), Harga, Kualitas Produk

b. Dependent Variabel: Kepuasan Konsumen Sumber: hasil pengolahan data dengan SPSS versi 20

Berdasarkan tabel 3 diperoleh nilai $r=$ 0,652 , yang artinya terdapat hubungan yang kuat dan positif antara kualitas produk dan harga dengan kepuasan konsumen pada produk WiFi.ID PT Telekomunikasi Indonesia Tbk. Witel Sumut, sesuai dengan kriteria hubungan pada tabel 4. Kemudian diperoleh nilai koefisien determinasi ( $R$ Square $)=0,425$, artinya kepuasan konsumen $(\mathrm{Y})$ pada produk WiFi.ID PT Telekomunikasi Indonesia Tbk. Witel Sumut sebesar $42,5 \%$ dipengaruhi oleh kualitas produk $\left(\mathrm{X}_{1}\right)$ dan harga $\left(\mathrm{X}_{2}\right)$, sedangkan selebihnya sebesar $57,5 \%$ dipengaruhi oleh variabel-variabel lain yang tidak dijelaskan pada penelitian ini, seperti promosi, pelayanan karyawan, biaya, lokasi, fasilitas, suasana, dan sebagainya.

\section{3) Uji Hipotesis}

a) Uji Simultan (Uji F)

Pengujian ini dilakukan secara simultan, yaitu dilakukan untuk menentukan diterima atau ditolaknya hipotesis. Pengujian hipotesis dilakukan untuk mengetahui apakah variabel kualitas produk dan harga yang diuji berpengaruh terhadap Kepuasan Konsumen. Jika $F_{\text {hitung }}>F_{\text {tabel }}$ atau signifikansi $\leq 0,05$, maka $\mathrm{H}_{0}$ ditolak.

Untuk menghasilkan suatu kesimpulan yang valid, maka harus dilakukan uji hipotesis dengan menggunakan program SPSS versi 20 Tabel 4

Hasil Uji Simultan (Uji F) ANOVA ${ }^{a}$

\begin{tabular}{|c|c|c|c|c|c|}
\hline Wovosi & 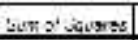 & $d 1$ & Los vonss & 1 & is \\
\hline repatorn & $\cos x, 0 \times 4$ & , & $y \cdot x: \%$ & $n \cdot \cos x$ & at \\
\hline isscicusi & Gew, u.2 & $\begin{array}{l}198 \\
111\end{array}$ & דו 13 & & \\
\hline
\end{tabular}

a. Dependent Variabel:Kepuasan Konsumen

b. Predictors: (Constant), Harga, Kualitas Produk

Sumber: hasil pengolahan data dengan SPSS versi 20

Berdasarkan tabel 4 di atas, diperoleh nilai $F_{\text {hitung }}$ sebesar $51,453>F_{\text {tabel }}$ dengan $(0,05$ ; 2 VS 139) dengan df = n-k-1 $(142-2-1=139)$ sebesar 3,06 atau dengan tingkat signifikansi $0,000 \leq \alpha 0,05$ maka $H_{0}$ ditolak, artinya kualitas produk dan harga berpengaruh positif dan signifikan terhadap kepuasan konsumen pada produk WiFi.ID PT Telekomunikasi Indonesia Tbk. Witel Sumut.

\section{b) Uji Parsial (Uji t)}

Pengujian ini dilakukan secara parsial yang dilakukan untuk menentukan diterima atau ditolaknya hipotesis. Pengujian hipotesis dilakukan untuk mengetahui apakah variabel kualitas produk dan harga yang diuji berpengaruh terhadap kepuasan konsumen. Jika $t_{\text {hitung }}>t_{\text {tabel }}$ atau signifikansi $\leq 0,05$, maka $\mathrm{H}_{0}$ ditolak.

Tabel 5

Perkiraan Nilai $t_{\text {hitung }}$ Coefficients $^{a}$

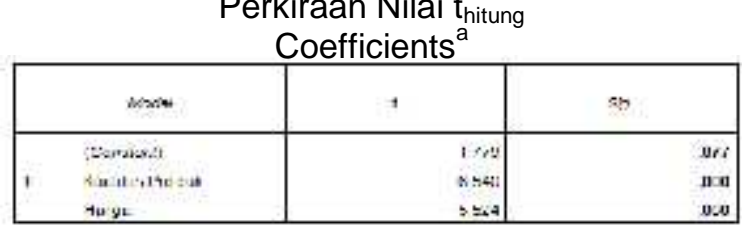


a. Dependent Variabel: Promosi Jabatan Sumber: hasil pengolahan data dengan SPSS versi 20

Berdasarkan tabel 5 diperoleh nilai $\mathrm{t}_{\text {hitung }}$ pada variabel $X_{1}$ (kualitas produk) sebesar $6,540>\mathrm{t}_{\text {tabel }}$ dengan $\mathrm{df}=\mathrm{n}-\mathrm{k}-1 \quad(142-2-1=139)$ sebesar 1,977 atau taraf signifikansi $0,000 \leq \alpha$ 0,05 , maka $\mathrm{H}_{0}$ ditolak, artinya kualitas produk berpengaruh positif dan signifikan terhadap kepuasan konsumen pada produk WiFi.ID PT Telekomunikasi Indonesia Tbk. Witel Sumut. Kemudian nilai $t_{\text {hitung }}$ pada variabel $\mathrm{X}_{2}$ (harga) sebesar 5,524 $>\mathrm{t}_{\text {tabel }}$ dengan $\mathrm{df}=\mathrm{n}-\mathrm{k}-1$ (142-2-1 $=139$ ) sebesar 1,977 atau taraf signifikansi $0,000 \leq \alpha 0,05$, maka $\mathrm{H}_{0}$ ditolak, artinya harga berpengaruh positif dan signifikan terhadap kepuasan konsumen pada produk WiFi.ID PT Telekomunikasi Indonesia Tbk. Witel Sumut.

\section{Evaluasi}

a. Kualitas Produk pada Produk WiFi.ID PT Telekomunikasi Indonesia Tbk. Witel Sumut

Dimensi kinerja, pada indikator kestabilan akses produk WiFi.ID memperoleh nilai ratarata 3,74. Untuk mengatasi hal ini, PT Telekomunikasi Tbk. sebaiknya meningkatkan kestabilan akses produk WiFi.ID dari gangguan atau masalah yang mungkin terjadi, agar aktivitas para konsumen produk WiFi.ID dalam menggunakan produk dapat berjalan lebih lancar. Pada indikator kecepatan akses produk WiFi.ID memperoleh nilai rata-rata 3,76. Bagi sebagian konsumen kecepatan akses yang dimiliki produk WiFi.ID sudah mampu memenuhi ekspektasi mereka, namun sebagian lainnya merasa kecepatan akses yang dimiliki produk WiFi.ID saat ini masih kurang memenuhi ekspektasi mereka. Oleh karena itu, sebaiknya PT Telekomunikasi Indonesia Tbk. menambah kecepatan akses untuk produk WiFi.ID.

Untuk dimensi reliabilitas, pada indikator kestabilan produk WiFi.ID dari gangguan jaringan memperoleh nilai rata-rata 3,54. Sebaiknya, PT Telekomunikasi Indonesia Tbk. meminimalisir adanya gangguan jaringan yang dapat mengganggu kelancaran penggunaan produk WiFi.ID. Kemudian, pada indikator petunjuk penggunaan (user guide) yang tertera pada voucher produk WiFI.ID memperoleh nilai rata-rata 3,66. Untuk mengatasi hal tersebut, dapat dilakukan pembaruan informasi petunjuk penggunaan (user guide) yang tertera pada voucher produk WiFi.ID agar lebih mudah dipahami oleh konsumen.

Selanjutnya untuk dimensi daya tahan, pada indikator proses registrasi yang dapat dilakukan selama voucher berada dalam masa aktif memperoleh nilai rata-rata 3,67. Sebaiknya, PT Telekomunikasi Indonesia Tbk. Witel Sumut lebih memperpanjang masa aktif atau pun menghapuskan sistem masa aktif, sehingga registrasi dapat dilakukan kapan saja tanpa mengacu pada masa aktif.

Dimensi estetika, pada indikator desain yang terdapat pada voucher produk WiFi.ID memperoleh nilai rata-rata 3,73. Sebaiknya, desain yang diterapkan pada voucher produk Wfi.ID diperbaharui sesuai tren terkini, sehingga desain nya tidak terlalu monoton. Sedangkan untuk dimensi kesesuaian dengan spesifikasi, pada indikator kesesuaian masa aktif yang tertera pada voucher produk WiFi.ID dengan masa aktif yang sebenarnya memperoleh nilai rata-rata 3,70. Untuk mengatasi hal tersebut, sebaiknya PT Telekomunikasi Indonesia Tbk. Witel Sumut memperjelas dan konsisten dengan batas masa aktif, sehingga para konsumen tidak keliru. Pada indikator kesesuaian spesifikasi kecepatan akses dengan kecepatan akses yang sebenarnya memperoleh nilai rata-rata 3,77 . Sebaiknya dilakukan penambahan access point di setiap lokasi yang memiliki hotspot WiFi.ID, agar kecepatan akses dapat sesuai dengan spesifikasi yang ditawarkan. Kemudian, pada indikator kesesuaian spesifikasi produk WiFi.ID dengan harapan konsumen memperoleh nilai rata-rata 3,69 . Untuk mengatasinya, dapat dilakukan peningkatan spesifikasi produk WiFi.ID agar dapat sesuai dengan harapan konsumen.

\section{b. Harga pada Produk WiFi.ID PT Telekomunikasi Indonesia Tbk. Witel Sumut}

Dimensi keterjangkauan harga, pada indikator harga produk WiFi.ID di outlet-outlet tidak berbeda dengan harga produk WiFi.ID di Plasa Telkom memperoleh nilai rata-rata 3,86. PT Telekomunikasi Indonesia Tbk. Witel Sumut dapat melakukan sosialisasi kepada outlet yang juga menjual voucher produk WiFi.ID tentang harga yang berlaku di seluruh Indonesia, agar tidak terjadi kesenjangan dengan harga yang terdapat di Plasa Telkom.

Kemudian dimensi diskon/potongan harga, pada indikator PT Telekomunikasi Indonesia Tbk. Witel Sumut memberikan diskon/potongan harga pada pembelian produk WiFi.ID memperoleh nilai rata-rata 3,72. Untuk mengatasinya, PT Telekomunikasi Indonesia Tbk. Witel Sumut dapat memberikan kompensasi berupa diskon/potongan harga kepada konsumen yang membeli dengan jumlah tertentu. Pada indikator diskon/potongan harga yang diberikan relatif banyak memperoleh nilai rata-rata 3,66. Sebaiknya, PT Telekomunikasi Indonesia Tbk Witel Sumut menambah besaran diskon/potongan harga untuk produk WiFi.ID. Pada indikator pemberian diskon/potongan harga yang diberikan bersifat rutin memperoleh nilai rata-rata 3,65 dengan kriteria jawaban setuju. Konsumen produk WiFi.ID menginginkan adanya pemberian diskon/potongan harga untuk pembelian produk 
WiFi.ID. Oleh karena itu, sebaiknya PT Telekomunikasi Indonesia Tbk. Witel Sumut memperhatikan keinginan konsumen tersebut dengan segera mewujudkannya.

\section{c. Kepuasan Konsumen pada Produk WiFi.ID PT Telekomunikasi Indonesia Tbk. Witel Sumut}

Dimensi kualitas produk, pada indikator reliabilitas/kehandalan pada produk WiFi.ID memperoleh nilai rata-rata 3,62. Untuk mengatasinya dapat dilakukan peningkatan serta penambahan reliabilitas/kehandalan yang dimiliki produk WiFi.ID. Pada indikator daya tahan yang dimiliki produk WiFi.ID memperoleh nilai rata-rata 3,67. PT Telekomunikasi Indonesia Tbk. Witel Sumut sebaiknya menambah masa aktif untuk produk WiFi.ID, sehingga penggunaannya dapat lebih lama. Pada indikator estetika yang dimiliki produk WiFi.ID memperoleh nilai rata-rata 3,61 . Untuk desain, dapat diterapkan desain yang up to date mengikuti tren terkini, misalnya menerapkan edisi untuk masing-masing voucher. Misalnya, ketika musim pertandingan sepak bola, desain yang digunakan menerapkan tema sepak bola, dan sebagainya. Selain itu, pilihan warna yang digunakan juga harus diperhatikan. Pada indikator kesesuaian dengan spesifikasi yang terdapat pada produk WiFi.ID memperoleh nilai rata-rata 3,64. Untuk mengatasinya, dapat dilakukan penyesuaian serta peningkatan spesifikasi yang dimiliki produk WiFi.ID.

Selanjutnya untuk dimensi kualitas pelayanan, pada indikator kemudahan dalam menyampaikan keluhan tentang produk WiFi.ID memperoleh nilai rata-rata 3,64. Untuk memudahkan konsumen dalam menyampaikan keluhan tentang produk WiFi.ID, PT Telekomunikasi Indonesia Tbk. Witel Sumut dapat menyediakan kolom keluhan atau kritik dan saran pada website yang ditentukan. Pada indikator respon yang diberikan oleh karyawan PT Telekomunikasi Indonesia Tbk. Witel Sumut dalam mengatasi keluhan konsumen mengenai produk WiFi.ID memperoleh nilai rata-rata 3,59. Untuk mengatasinya, sebaiknya memberikan respon yang cepat ketika ada keluhan dari konsumen, demi kenyamanan bersama. Pada indikator kemampuan karyawan PT Telekomunikasi Indonesia Tbk. Witel Sumut dalam memberikan solusi atas keluhan konsumen mengenai produk WiFi.ID memperoleh nilai rata-rata 3,62. Untuk mengatasinya, dapat dilakukan dengan meningkatkan kepedulian terhadap konsumen, yang dapat diterapkan melalui penanganan yang cepat dan tepat terhadap setiap keluhan konsumen.

Untuk dimensi harga, pada indikator intensitas pemberian diskon/potongan harga memperoleh nilai rata-rata 3,54. Untuk mengatasinya, maka perlu dilakukan peningkatan dalam hal pemberian diskon/potongan harga untuk pembelian produk WiFi.ID. Sedangkan untuk dimensi promosi, pada indikator pemberian promo produk WiFi.ID memperoleh nilai rata-rata 3,65. Untuk mengatasinya, dapat dilakukan pemberian promo yang menarik agar dapat meningkatkan minat beli konsumen. Pada indikator intensitas pemberian promo produk WiFi.ID memperoleh nilai rata-rata 3,53 . Sebaiknya dilakukan penambahan intensitas pemberian promo untuk produk WiFi.ID agar meningkatkan antusias konsumen untuk menggunakan produk WiFi.ID. Sedangkan pada indikator kuantitas promo yang diberikan untuk produk WiFi.ID memperoleh nilai rata-rata 3,53. Untuk mengatasi hal tersebut, dapat dilakukan peningkatan untuk kuantitas promo pada produk WiFi.ID agar lebih banyak konsumen yang dapat menikmati promo yang diberikan.

\section{KESIMPULAN DAN SARAN}

\section{Kesimpulan}

a. Hasil analisis deskriptif kualitatif tentang kualitas produk secara keseluruhan dapat dilihat bahwa nilai rata-rata untuk variabel kualitas produk berdasarkan jawaban responden adalah 3,78 dengan kriteria jawaban baik. Nilai rata-rata yang tertinggi sebesar 3,93 dengan kriteria jawaban baik diperoleh dimensi fitur (features) pada indikator kapasitas kuota yang tidak terbatas (unlimited) pada produk WiFi.ID. Sedangkan nilai rata-rata terendah sebesar 3,54 dengan kriteria jawaban baik diperoleh dimensi reliabilitas (reliability) pada indikator kestabilan produk WiFi.ID dari gangguan jaringan.

b. Hasil analisis deskriptif kualitatif tentang harga secara keseluruhan dapat dilihat bahwa nilai rata-rata variabel harga adalah sebesar 3,87 dengan kriteria jawaban setuju. Nilai rata-rata tertinggi sebesar 4,13 dengan kriteria jawaban setuju diperoleh dimensi keterjangkauan harga pada indikator haga produk WiFi.ID dapat dijangkau oleh konsumen. Sedangkan nilai rata-rata yang terendah sebesar 3,65 dengan kriteria jawaban setuju diperoleh dimensi diskon/potongan harga pada indikator pemberian diskon/potongan harga yang diberikan bersifat rutin.

c. Hasil analisis deskriptif kualitatif tentang kepuasan konsumen secara keseluruhan dapat dilihat bahwa nilai rata-rata variabel kepuasan konsumen adalah sebesar 3,68. Nilai rata-rata tertinggi adalah sebesar 3,94 dengan kriteria jawaban puas diperoleh dimensi harga dengan indikator keterjangkauan harga produk WiFi.ID. Sedangkan nilai rata-rata terendah adalah sebesar 3,53 dengan kriteria jawaban puas diperoleh dimensi promosi, dengan indikator 
intensitas pemberian promo produk WiFi.ID dan indikator kuantitas promo yang diberikan untuk produk WiFi.ID.

d. Hasil analisis regresi linier berganda yang dihitung menggunakan program SPSS Versi 20 adalah $\mathrm{Y}=9,934+0,428 \mathrm{X}_{1}+0,733 \mathrm{X}_{2}$. Artinya, terdapat pengaruh yang positif antara variabel kualitas produk $\left(\mathrm{X}_{1}\right)$ dan harga $\left(X_{2}\right)$ terhadap variabel kepuasan konsumen (Y) pada produk WiFi.ID PT Telekomunikasi Indonesia Tbk. Witel Sumut.

e. Dari hasil analisis korelasi diperoleh nilai $r$ sebesar 0,652 yang berarti terdapat hubungan yang kuat dan positif antara kualitas produk $\left(X_{1}\right)$ dan harga $\left(X_{2}\right)$ dengan kepuasan konsumen $(\mathrm{Y})$ pada produk WiFi.ID PT Telekomunikasi Indonesia Tbk. Witel Sumut. Kemudian diperoleh nilai koefisien determinasi ( $\mathrm{R}$ Square) sebesar 0,425 yang berarti kepuasan konsumen $(Y)$ pada produk WiFi.ID PT Telekomunikasi Indonesia Tbk. Witel Sumut sebesar 42,5\% dipengaruhi oleh kualitas produk $\left(\mathrm{X}_{1}\right)$ dan harga $\left(X_{2}\right)$, sedangkan selebihnya sebesar $57,5 \%$ dipengaruhi oleh variabel-variabel lain yang tidak dijelaskan pada penelitian ini, seperti biaya, lokasi, promosi, kualitas pelayanan, fasilitas, suasana dan sebagainya.

f. Hasil pengujian hipotesis secara simultan dengan uji $F$, dapat diketahui bahwa terdapat pengaruh yang positif dan signifikan antara variabel kualitas produk dan harga terhadap kepuasan konsumen, dimana nilai $F_{\text {hitung }}$ sebesar $51,453>F_{\text {tabel }}$ dengan $(0,05 ; 2 \mathrm{VS}$ 139) dengan $\mathrm{df}=\mathrm{n}-\mathrm{k}-1 \quad(142-2-1=139)$ sebesar 3,06 atau dengan tingkat signifikansi $0,000 \leq \alpha \quad 0,05$ maka $H_{0}$ ditolak, artinya kualitas produk dan harga berpengaruh positif dan signifikan terhadap kepuasan konsumen pada produk WiFi.ID PT Telekomunikasi Indonesia Tbk. Witel Sumut.

g. Hasil pengujian hipotesis secara parsial dengan uji t, dapat diketahui bahwa terdapat pengaruh yang positif dan signifikan antara variabel kualitas produk dan harga terhadap kepuasan konsumen, dimana nilai $t_{\text {hitung }}$ pada variabel $X_{1}$ (kualitas produk) sebesar 6,540 > $t_{\text {tabel }}$ dengan $\mathrm{df}=\mathrm{n}-\mathrm{k}-1 \quad(142-2-1=139)$ sebesar 1,977 atau taraf signifikansi $0,000 \leq$ $\alpha 0,05$, maka $\mathrm{H}_{0}$ ditolak, artinya kualitas produk berpengaruh positif dan signifikan terhadap kepuasan konsumen pada produk WiFi.ID PT Telekomunikasi Indonesia Tbk. Witel Sumut. Kemudian nilai $t_{\text {hitung }}$ pada variabel $\mathrm{X}_{2}$ (harga) sebesar 5,524 $>\mathrm{t}_{\text {tabel }}$ dengan df $=\mathrm{n}-\mathrm{k}-1(142-2-1=139)$ sebesar 1,977 atau taraf signifikansi $0,000 \leq \alpha 0,05$, maka $\mathrm{H}_{0}$ ditolak, artinya harga berpengaruh positif dan signifikan terhadap kepuasan konsumen pada produk WiFi.ID PT Telekomunikasi Indonesia Tbk. Witel Sumut.

\section{Saran}

a. Untuk meningkatkan kualitas produk pada produk WiFi.ID PT Telekomunikasi Indonesia Tbk. Witel Sumut, maka perlu dilakukan peningkatan kestabilan akses produk WiFi.ID, menambah kecepatan akses, serta meningkatkan spesifikasi produk WiFi.ID agar dapat sesuai dengan harapan konsumen.

b. Untuk mempertahankan harga yang terjangkau bagi konsumen, PT Telekomunikasi Indonesia Tbk. sebaiknya memberikan kompensasi berupa diskon/potongan harga kepada konsumen yang membeli dengan jumlah tertentu, dan menambah besaran diskon/potongan harga.

c. Untuk mempertahankan serta meningkatkan kepuasan konsumen, PT Telekomunikasi Indonesia Tbk. Witel Sumut perlu meningkatkan kepedulian kepada konsumen mengenai keinginan konsumen, serta memberi respon yang baik dan cepat terhadap keluhan yang dirasakan konsumen mengenai produk WiFi.ID.

\section{E. DAFTAR PUSTAKA}

Alma, Buchari. 2000. Manajemen Pemasaran dan Pemasaran Jasa, Edisi Revisi. Bandung: Alfabeta.

Kotler, Philip dan Gary Armstrong. 2001. Prinsip-Prinsip Pemasaran. Jakarta: Erlangga.

2008. Prinsip-Prinsip Pemasaran, Edisi Keduabelas, Jilid 1. Jakarta: Erlangga.

Kotler, Philip dan Kevin Lane Keller. 2009. Manajemen Pemasaran, Edisi Ketigabelas, Jilid 1. Jakarta: Erlangga.

Kotler, Philip. 2005. Manajemen Pemasaran, Jilid 2, Edisi Kesebelas. Jakarta: PT Indeks.

Lupiyoadi, Rambat dan Hamdani. 2001. Manajemen Pemasaran Jasa. Jakarta: Salemba Empat.

Prawirosentono, Suyadi. 2007. Filosofi Baru Tentang Manajemen Mutu Terpadu Abad 21: Kiat Membangun Bisnis Kompetitif. Jakarta: Bumi Aksara.

Sumarwan, Ujang. 2004. Perilaku Konsumen: Teori dan Penerapannya Dalam Pemasaran. Jakarta: Ghalia Indonesia.

Tjiptono, Fandy. $2001 . \quad$ Strategi Pemasaran. Yogyakarta: Andi. 